\title{
Oatp-associated uptake and toxicity of microcystins in primary murine whole brain cells
}

\author{
D. Feurstein, K. Holst, A. Fischer, D.R. Dietrich * \\ Human and Environmental Toxicology, University of Konstanz, Konstanz, Germany
}

\begin{abstract}
A B S T R A C T
Microcystins (MCs) are naturally occurring cyclic heptapeptides that exhibit hepato-, nephro- and possibly neurotoxic effects in mammals. Organic anion transporting polypeptides (rodent Oatp/human OATP) appear to be specifically required for active uptake of MCs into hepatocytes and kidney epithelial cells. Based on symptoms of neurotoxicity in MC-intoxicated patients and the presence of Oatp/OATP at the blood-brainbarrier (BBB) and blood-cerebrospinal-fluid-barrier (BCFB) it is hypothesized that MCs can be transported across the BBB/BCFB in an Oatp/OATP-dependent manner and can induce toxicity in brain cells via inhibition of protein phosphatase (PP). To test these hypotheses, the presence of murine Oatp (mOatp) in primary murine whole brain cells (mWBC) was investigated at the mRNA and protein level. MC transport was tested by exposing $\mathrm{mWBC}$ to three different MC-congeners (MC-LR, -LW, -LF) with/without co-incubation with the OATP/Oatp-substrates taurocholate (TC) and bromosulfophthalein (BSP). Uptake of MCs and cytotoxicity was demonstrated via MC-Western blot analysis, immunocytochemistry, cell viability and PP inhibition assays. All MC congeners bound covalently and inhibited mWBC PP. MC-LF was the most cytotoxic congener followed by $-\mathrm{LW}$ and $-\mathrm{LR}$. The lowest toxin concentration significantly reducing mWBC viability after $48 \mathrm{~h}$ exposure was $400 \mathrm{nM}$ (MC-LF). Uptake of MCs into mWBCs was inhibited via co-incubation with excess TC $(50$ and $500 \mu \mathrm{M})$ and $\mathrm{BSP}(50 \mu \mathrm{M})$. MC-Western blot analysis demonstrated a concentration-dependent accumulation of MCs. In conclusion, the in vitro data support the assumed MC-congener-dependent uptake in a mOatp-associated manner and cytotoxicity of MCs in primary murine whole brain cells.
\end{abstract}

\section{Introduction}

Contamination of natural waters by cyanobacterial blooms represents a worldwide problem, causing serious water pollution and health hazards to humans and livestock. Human health problems are most likely associated with chronic exposure to low microcystin (MC) concentrations in poorly treated drinking water, contaminated food, e.g. fish, water snails, prawns, etc., and with the intentional consumption of Aphanizomenon flos-aquae (AFA)-based Blue-Green Algae Supplements (BGAS), shown to be contaminated with cyanotoxins, specifically MCs, (Schaeffer et al., 1999; Gilroy et al., 2000; Lawrence et al., 2001). MCs are the most commonly found group of cyclic heptapeptide cyanotoxins with molecular weights ranging between 900 and 1100 Dalton (Da), represent more than 80 structural variants differing in the two variable L-amino acids (Meriluoto and Spoof, 2008).

The in vivo and in vitro toxicity of MCs is primarily governed by the potent inhibition of serine/threonine-specific protein phosphatases (PPs) (Eriksson et al., 1990: MacKintosh et al., 1990: MacKintosh and MacKintosh, 1994; Toivola et al., 1994), specifically PP1, PP2A, PP4 and

\footnotetext{
- Corresponding author. Fax; +497531883170

E-mail address: daniel.dietrich@uni-konstanz.de (D.R. Dietrich).
}

PP5 (Hastie et al., 2005). As a consequence of PP inhibition numerous cellular proteins e.g. intermediate filaments, are hyperphosphorylated, thereby leading to the collapse of the cytoskeleton and loss of cellular integrity (Eriksson et al., 1989; Wickstrom et al., 1995; Batista et al., 2003). Cellular necrosis and apoptosis is observed in a dose- and time dependent manner, whereby apoptosis is observed at lower concentrations than overt necrosis (Mankiewicz et al., 2001; Fladmark et al., 2002; Gehringer, 2004; Fu et al., 2005; Weng et al., 2007). Due to their structure and size MCs do not readily penetrate the cell membrane via simple diffusion but rather require the presence of multi-specific organic anion transporting polypeptides (rodent Oatp/ human OATP) for active uptake (Runnegar et al., 1991: Fischer et al., 2005; Komatsu et al., 2007; Monks et al., 2007). It is thus not surprising that co-incubation of MCs, e.g. MC-LR, with the known Oatp/OATP substrates choline, taurocholate (TC) and bromosulfophthalein (BSP) reduces the uptake of MC in vitro (Runnegar et al.. 1995; Fischer et al., 2005; Komatsu et al., 2007; Meier-Abt et al., 2007; Monks et al., 2007). Moreover, a knock-out mouse lacking expression of mOatp1b2 in the liver presented with no overt liver pathology when exposed to MC-LR (Lu et al., 2008), while the wild-type counterpart showed the typical hepatotoxicity observed in i.p. or oral MC-LR in vivo exposure experiments with mice (Ito et al., 2000). Oatp/ OATP are primarily expressed in enterocytes, hepatocytes and renal 
epithelial cells (Kullak-Ublick et al., 1994; Bergwerk et al., 1996; Abe et al., 1999; König et al., 2000a; König et al., 2000b; Kullak-Ublick et al., 2004; Mikkaichi et al., 2004; Sai et al., 2006; Naud et al., 2007: Tani et al., 2008) as well as in the heart, lung, spleen, pancreas, brain and the blood-brain-barrier (BBB) (Hagenbuch and Meier, 2003; Hagenbuch and Meier, 2004). Consequently, the systemic distribution of MCs is governed by the degree of blood perfusion and the type and expression level of Oatp/OATP present in a given organ. Due to the first-pass effect, high blood perfusion and high expression level of multiple Oatp/OATP types, MCs are often characterized as hepatotoxins, although other organs may also be affected. Indeed, Fischer and Dietrich (2000a, 2000b) treated carp (Cyprinus carpio) with a single dose of $400 \mu \mathrm{g} / \mathrm{kg}$ bw MC-LR and demonstrated pathological changes in the hepatopancreas and kidney as well as the presence of MC-LR in several organs including the brain $48 \mathrm{~h}$ post toxin application (Fischer and Dietrich, 2000a). Immunoblotting of brain homogenates with antiMC-LR antibody revealed a band with molecular weight of approximately $38 \mathrm{kDa}$, corresponding to the catalytic subunits of PP1 and PP2A ( $37 \mathrm{kDa}$ ), thus corroborating the interaction of MC-LR with PPs in the brain. A comparable study with mice demonstrated the rapid appearance of MC-LR in the brain, $45 \mathrm{~min}$ and $60 \mathrm{~min}$ after the initial intraperitoneal (i.p.) or peroral (p.o.) administration, respectively (Meriluoto et al., 1990; Nishiwaki et al., 1994). As well as detection of MC, pathological changes of the brain anatomy were observed in five day old progeny of mice which had been treated with a toxic extract of Microcystis aeruginosa. Of these neonatal mice $10 \%$ showed a reduced brain size and some presented with extensive pathology in the outer region of the hippocampus (Falconer et al, 1988). The above data suggest that as a consequence of the high blood perfusion of the brain, significant amounts of MC could reach the brain across the BBB and induce brain pathology. Indeed, the above hypothesis is supported by the tragic events in February 1996, where 131 patients at a hemodialysis clinic in Caruaru. Brazil, employing poorly treated drinking water and overly used dialysis cartridges, were exposed intravenously to varying concentrations of MC-congeners (MC-YR/-LR/-AR) (Jochimsen et al., 1998; Carmichael et al., 2001; Azevedo et al., 2002; Soares et al., 2006). Of these MCexposed patients (mean approximate value of $19.5 \mu \mathrm{g} \mathrm{MC}$ cquiv. $/ \mathrm{l}$ in dialysis water (Carmichael et al., 2001)), 89\% developed immediate signs of neurotoxicity (e.g. dizziness, tinnitus, vertigo, headache, vomiting, nausea, mild deafness, visual disturbance and blindness) with a later onset of overt hepatotoxicity and finally succumbed to multi-organ failure. Of the patients exposed 76 patients died within 10-weeks of initial intravenous exposure (Pouria et al., 1998).

Different Oatp/OATP types appear to have varying affinities for MCs. Indeed, uptake of MC-LR in vitro via liver-specific OATP1B1, 1B3, Oatp1b2 (mouse, rat), Oatp1d1 (skate) as well as the more widely distributed (kidney, liver, BBB) OATP1A2 has previously been described (Fischer et al., 2005; Komatsu et al., 2007; Meier-Abt et al., 2007; Monks et al., 2007; Lu et al., 2008). Thus the observed liver failure in the Caruaru incident was most likely a direct consequence of the liver-specific uptake of MCs via OATP, e.g. OATP1B1 and 1B3 (Fischer et al., 2005; Komatsu et al., 2007; Monks et al., 2007). whereas the immediate neurotoxicity may be explained by OATPmediated transport, e.g. OATP1A2 (Fischer et al., 2005), of MCs across the BBB. Indeed, OATP1A2 is highly expressed in endothelial cells of the $\mathrm{BBB}$, epithelial cells of the blood-cerebrospinal-fluid-barrier (BCFB) and in the cell membrane of human neurons (Kullak-Ublick et al., 1995; Gao et al., 2000; Gao et al., 2005; Lee et al., 2005; Nies, 2007).

Of the mouse Oatps, mOatp1a1, mOatp1a4, mOatp1a5, and mOatp1a6 belong to the same OATP1A family, i.e. having greater than $60 \%$ amino acid sequence identity, as the human OATP1A2 (Hagenbuch and Meier, 2004). Similarly the mOatp1b2 belongs to the same OATP1B family as the rat rOatp1b2 and the human OATP1B1 and
OATP1B3, while the mOatp1c1 belongs to the OATP1C family with the human OATP1C1. However, in contrast to the known transporting capabilities of the human OATP (1A2, 1B1, 1B3) (Fischer et al., 2005; Komatsu et al., 2007; Monks et al., 2007), it is currently not known whether or not the latter also applies to human OATP1C1. The most recent comparison of the skate Oatp1d1, demonstrated to be able to transport MC-LR at a low level, with other OATPS of the OATP family tree (Hagenbuch and Meier, 2004), suggests that the skate Oatp $1 \mathrm{~d} 1$ is an evolutionarily ancient precursor of the mammalian-liver OATP1B family, however exerts the highest degree of homology (50.4\% amino acid sequence identity) with the human OATP1C1 of the OATP1C family (Meier-Abt et al., 2007). Based on the degree of evolutionary conservation of mOatp, as denoted by the high amino acid sequence identity with human OATP demonstrated to being capable of transporting MC, it was assumed that mouse Oatp have similar MC transporting capabilities. Indeed, the latter assumption is at least partially corroborated by Lu et al. (2008), who demonstrated lack of acute MC-induced hepatotoxicity in mOatp1b2-knock-out mice. Moreover, as mouse Oatp1a1, 1a4, 1a5, 1c1, 2b1, and 3a1 were demonstrated to be expressed (mRNA level) in the mouse brains (Hagenbuch and Meier, 2004; Cheng et al., 2005), the question was raised whether one or more of these mOatps, i.e. 1a 1, 1a5, 1c1, and 3a1, could be involved in transporting MC into neuronal cells. Mouse Oatps $1 \mathrm{~b} 2$ and $6 \mathrm{~d} 1$ were included in the analysis as mOatp1b2 was assumed to be primarily expressed in the liver (Cheng et al., 2005; Lu et al., 2008) while no knowledge on brain expression was available for mOatp 6d1.

In order to test the hypothesis that MCs are taken up actively into neuronal cells in a mOatp-associated and MC-congener-dependent manner, the presence of mOatp in primary murine whole brain cells ( $\mathrm{mWBC}$ ) was verified at the MRNA and protein level. MC transport and neuronal toxicity was tested with three MC congeners (MC-LR, -LW, -LF) with/without co-incubation with the OATP/Oatp substrates TC and BSP. Uptake of MCs was demonstrated indirectly via cytotoxicity measurements and directly via MC-Western blot analysis, protein phosphatase inhibition determination, and via MC-specific immunocytochemistry in mWBC cultures exposed to MCs.

\section{Materials and methods}

\section{Chemicals and reagents}

All chemicals, unless otherwise stated were of the highest analytical grade commercially available. Individual MC-congeners (MC-LR, -LW and -LF) were obtained from Alexis Biochemicals, Lausen, Switzerland: Okadaic acid (OA) from Sigma-Aldrich, Taufkirchen, Germany.

Ham's F12 medium (F12), minimal essential medium (MEM), Iscove's modified DMEM (IMDM), fetal bovine serum (FBS), penicillin/ streptomycin and G-418-sulphate (Geneticin) were purchased from PAA Laboratories, Pasching, Austria and poly-L-lysine, trypsin, trypsin inhibitor and bovine serum albumin (BSA) were obtained from SigmaAldrich, Taufkirchen, Germany.

$\left.{ }^{32} \mathrm{P}\right]-\mathrm{ATP}$ and Amersham ECL Plus Western blotting detection reagents were purchased from GE Healthcare, Munich, Germany; Adenosine 5 '-triphosphate disodium salt, phosphorylase $b$ from rabbit muscle and phosphorylase kinase from rabbit muscle from SigmaAldrich, Taufkirchen, Germany and protease inhibitor cocktail set III was obtained from Calbiochem, San Diego, U.S.A.

For reverse transcription-Polymerase Chain Reaction (RT-PCR), MMuLV RT (1000 u), $5 \times$ reaction buffer (supplied with M-MuLV RT), Oligo(dT) 18 primer $(100 \mu \mathrm{M})$, random hexamer primer $(100 \mu \mathrm{M})$, dNTP Mix (10 mM), Ribonuclease Inhibitor (RiboLock, $2500 \mathrm{u}$ ) and for PCR the $2 \times$ PCR Master Mix were obtained from Fermentas, St. Leon-Rot, Germany. Primer pairs were purchased from MWG-Biotech, Martinsried, Germany. 
Specific pathogen-free Balb/c mice were obtained from The Jackson Laboratory, Bar Harbor, U.S.A. and held at the animal facility, University of Konstanz, Cermany. Euthanasia and organ removal was carried out in accordance with the German Animal Protection Law, approved by the relevant German authority, the Regierungspräsidium in Freiburg, Germany (registry number: T-07 05).

\section{Isolation, cell culture and characterization of primary murine WBC}

Six-to seven-day-old pups were decapitated and whole brains were immediately removed, cut into small pieces and then trypsinized in HIB solution $(120 \mathrm{mM} \mathrm{NaCl}, 5 \mathrm{mM} \mathrm{KCl}, 25 \mathrm{mM}$ HEPES, $9.1 \mathrm{mM}$ Glucose) containing $2.5 \mathrm{~g} / \mathrm{l}$ trypsin for $12 \mathrm{~min}$ at $37{ }^{\circ} \mathrm{C}$. Trypsin inhibitor ( $3.75 \mathrm{~g} / \mathrm{l})$ was added and $\mathrm{mWBC}$ were centrifuged for $5 \mathrm{~min}$ at $300 \times \mathrm{g}$. The supernatant was discarded and the resuiting pellet was re-suspended in culture medium ( $1: 1$ ( $/ \mathrm{v} / \mathrm{v})$ IMDM/F12, supplemented with $10 \%$ heat inactivated FBS and $1 \%$ penicillin-streptomycin). Cells were gently triturated with a 1.5 inch 21 gauge needle and then filtered through a $100 \mu \mathrm{m}$ nylon mesh. The dissociated $\mathrm{mWBC}$ were seeded in poly-L-lysine ( $50 \mathrm{mg} / \mathrm{l}$ ) coated 6 and 96 well plates (Greiner Bio-One, Frickenhausen, Germany) and 8 well chamber slides (BioCoat; BD, Heidelberg, Germany) at a density of $1.6 \times 10^{6}$ cells $/ \mathrm{ml}$ and cultured at $37{ }^{\circ} \mathrm{C}$ and $5 \% \mathrm{CO}_{2}$. Culture media was renewed every $72 \mathrm{~h}$.

To characterize the primary murine whole brain cells ( $\mathrm{mWBC}$ ), Western blots were carried out using brain cell-type specific antibodies kindly provided by Prof. Leist (Doerenkamp-Zbinden Chair of Alternative in-vitro Methods, University of Konstanz). Briefly, following 8 days of in vitro cultivation, the presence of neurons, astrocytes, microglia, endothelial cells and fibroblasts in the mWBC culture, as well as in homogenates of whole brains of six-day-old pups, was assessed via Western blot using antibodies to anti-class III $\beta$ tubulin (1:1000; Covance, Emeryville, U.S.A; Fig. 1A), anti-glial fibrillary acidic protein (1:1000; Sigma-Aldrich, Taufkirchen, Germany; Fig. 1B), anti-F4/80 (1:1000; AbD serotec, Martinsried, Germany; Fig. 1C) and anti-vimentin (1:1000; developmental studies hybridoma bank, university of lowa, U.S.A). Positive signals were observed in mWBC for neurons, astrocytes and microglia (Figs. 1A-C), vimentin, representing endothelial cells and fibroblast type cells, could not be detected (figure not shown), corroborating earlier findings in mWBC (Bologa et al., 1983).

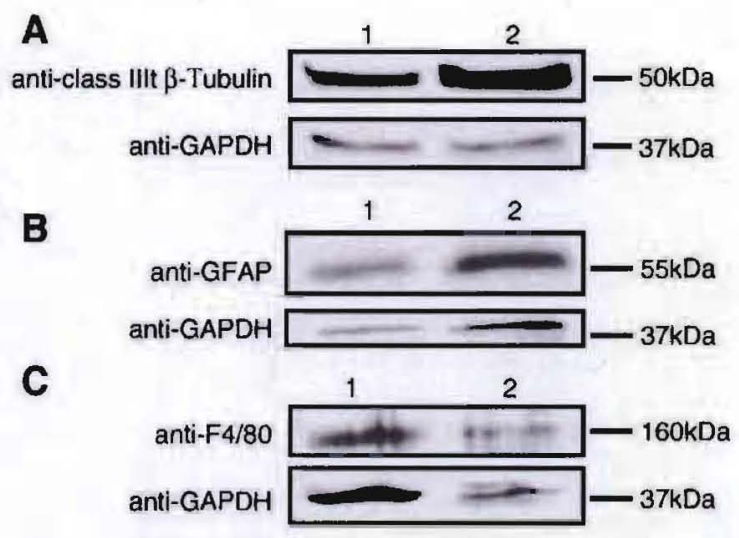

Fig. 1. Characterization of $\mathrm{mWBC}$ using cell type-specific antibodies and Western blot. (A) Neuron-specific class III ( 3 -tubulin antibody in mWBC (lane 1,15 ug total protein) and murine brain homogenate (lane 2,15 $\mu$ total protein). (B) Astrocyte-specific glial fibrillary acidic protein (GFAP) antibody in mWBC (lane I, $20 \mu \mathrm{g}$ total protein) and murine brain homogenate (lane 2, 20 ug total protein). (C) MCA497G antibody against murine microglial surface protein $\mathrm{F} 4 / 80$ in mWBC (lane 1, $40 \mu \mathrm{g}$ total protein) and murine brain homogenate (lane 2, $20 \mu \mathrm{g}$ total protein).
mWBC were cultured for $7-8$ days ( $70-80 \%$ confluency) and incubated for $48 \mathrm{~h}$ with the toxins. MC-LR, - LW and - LF were dissolved in $75 \%$ methanol (MeOH), TC, BSP and OA in water.

Incubation with $70 \mathrm{nM} O A$ served as positive control ( $0 \%$ survival) in cytotoxicity studies. $\mathrm{mWBC}$ incubated with culture medium only served as negative control ( $100 \%$ survival). The concentration of $\mathrm{MeOH}$ never exceeded $0.5 \%$, which served as solvent control in all experiments. No differences in viability, condition or growth rate could be identified between solvent and negative control. For co-incubation studies a single MC-congener was incubated with TC (ACROS, Geel, Belgium) or BSP (Sigma-Aldrich, Taufkirchen, Germany) in excess (50 and $500 \mu \mathrm{M}$ ) for $48 \mathrm{~h}$. TC and BSP alone demonstrated no reduction of cell viability at the concentrations used (data not shown).

Determination of MC uptake in $m W B C$ via Western blot analysis (WB) and immunocytochemistry (ICC)

Western blot. The medium of MC-exposed mWBC was removed, cells were washed 3 times with phosphate-buffered saline (PBS) and homogenized in $60 \mu$ ice-cold extraction buffer $(10 \mathrm{mM}$ triethanolamine (Tris)-base, $\mathrm{pH} 7.5,140 \mathrm{mM} \mathrm{NaCl}, 5 \mathrm{mM}$ EDTA, $0.1 \%(v / v)$ Triton X-100.1× protease inhibitor cocktail). To remove cell membrane fragments, the lysate was centrifuged for $5 \mathrm{~min}$ at $16,000 \times \mathrm{g}$ and $4{ }^{\circ} \mathrm{C}$. The protein content was determined by the method of Bradford (Bradford, 1976) (Bio-Rad Protein Assay; Bio-Rad, Munich, Germany) and equal protein amounts (30 $\mu \mathrm{g} / \mathrm{lane}$ ) were separated using a $10 \%$ sodium dodecyl sulfate-polyacrylamide gel electrophoresis (SDS-PACE) according to the method of Laemmli (1970) at constant $200 \mathrm{~V}$. Following electrophoresis, proteins were transferred onto nitrocellulose membranes (Whatman, Dassel, Germany) at $300 \mathrm{~mA}$ for $90 \mathrm{~min}$ as previously described (Tobwin et al., 1979). Membranes were incubated with blocking buffer (TTBS - Tris-buffered saline with Tween $20(100 \mathrm{mM}$ Tris-HCl, 0.9\% (w/v) $\mathrm{NaCl}, \mathrm{pH} 7.6,0.1 \%(\mathrm{w} / \mathrm{v})$ Tween 20 ) containing $1 \%$ bovine serum albumine (BSA) for $30 \mathrm{~min}$ at RT and incubated with polyclonal rabbit anti-MCLR\#2 (1:500) (Mikhailov et al., 2001), monoclonal mouse anti-ADDA (1:700) (clone AD4G2, Alexis Biochemicals, Lausen, Switzerland), monoclonal mouse anti-PP1 $\alpha$ (1:500) (Sigma-Aldrich, Taufkirchen, Germany), monoclonal mouse antiPP2A/C (1:1000) (Upstate, Temecula, U.S.A.) and monoclonal mouse anti-GAPDH $(1: 30,000)$ (Sigma-Aldrich, Taufkirchen, Germany) for $16 \mathrm{~h}$ at $4{ }^{\circ} \mathrm{C}$. Secondary antibodies were horseradish peroxidase (HRP)-conjugated mouse anti-rabbit- $(1: 50,000)$ (Sigma-Aldrich. Taufkirchen, Germany) and goat anti-mouse (1:20,000) (SigmaAldrich, Taufkirchen, Germany) antibodies. Immunopositive bands were visualized via $\mathrm{ECl}$ substrate according to the manufacturer's recommendations and the resulting chemiluminescent signal was detected using Fujifilm LAS-1000 (FUJIFILM Electronic Imaging, Kleve, Germany). For re-probing nitrocellulose membranes, blots were stripped using $50 \mathrm{ml}$ of $50{ }^{\circ} \mathrm{C}$ stripping buffer $(50 \mathrm{mM}$ Trisbase, $2 \%$ (w/v) SDS, pH 6.8, $100 \mathrm{mM}$ B-mercaptoethanol) for $30 \mathrm{~min}$ under gentle shaking.

Immunocytochemistry. The medium of MC-exposed $\mathrm{mWBC}$ was removed, cells were washed 3 times with PBS and fixed in $-20^{\circ} \mathrm{C}$ cold ethanol/acetone $(1: 1)$ for $2 \mathrm{~min}$ on ice. The fixation buffer was discarded and the chamber slides were air dried for $30 \mathrm{~min}$ and stored at $-20^{\circ} \mathrm{C}$. For the detection of MC, $m W B C$ were re-hydrated in PBS and incubated in blocking buffer containing $1 \%$ BSA for 30 min. Rabbit anti-MCLR\#2 antibody (1:500) (Mikhailov et al., 2001) was applied in a humidified atmosphere and incubated for $60 \mathrm{~min}$ at RT. The fluorochrome-conjugated secondary antibody (1:500) goat antirabbit-Alexa488 ( $\lambda_{\max }: 495 \mathrm{~nm}$; Invitrogen, Karlsruhe, Germany), was added and samples were incubated for $60 \mathrm{~min}$ at RT. For 
cytoskeleton detection a concentration of $700 \mathrm{nM}$ TRITC-phalloidin ( $\lambda_{\max }: 547 \mathrm{~nm}$ : Sigma-Aldrich, Taufkirchen, Germany) was used to stain actin filaments and nuciei were counterstained with $2.5 \mu \mathrm{M}$ Hoechst 33342 ( $\lambda_{\max }: 352 \mathrm{~nm}$; Invitrogen, Karlsruhe, Germany). Finally, culture slides were mounted with Fluorescent Mounting Medium (DAKO, Hamburg, Germany) and visualized using a con-focal microscope (LSM 510 META, Zeiss, Göttingen, Germany).

\section{Determination of MC-congener specific cytotoxic effects in $\mathrm{mWBC}$}

Cytotoxicity assay. mWBC cell viability was assessed by determination of 3-(4,5 dimethylthiazol-2-yl)-2,5-diphenyl tetrazolium bromide (MTT) reduction according to Mosmann (1983). Briefly, after $48 \mathrm{~h}$ toxin exposure, $25 \mu$ MTT solution $(5 \mathrm{mg} / \mathrm{ml}$, ACROS, Geel, Belgium) was added to each well and incubated for $90 \mathrm{~min}$ at $37{ }^{\circ} \mathrm{C}$. After incubation the medium was gently removed and $100 \mu \mathrm{l}$ solubilization buffer ( $95 \%(\mathrm{v} / \mathrm{v})$ isopropanol, $5 \%(\mathrm{v} / \mathrm{v})$ formic acid) was added to each well, shaken carefully for at least $15 \mathrm{~min}$ to re-dissolve the formazan product. Absorption was measured at $550 \mathrm{~nm}$ using a microtiter plate reader (Tecan, Crailsheim, Germany). The test was carried out independently three times in duplicates for each congener.

Radioactive protein phosphatase inhibition assay (rPPIA). Phosphorylation of phosphorylase b with [ $\left.{ }^{32} \mathrm{P}\right]-\mathrm{ATP}$ and the protein phosphatase inhibition assay were performed as described by Fischer and Dietrich (2000c).

In a preliminary step, cell extracts of untreated mWBC were taken through a dilution series with extraction buffer (see immunoblotting) in order to determine the linear range of dephosphorylation of the $\left[{ }^{32} \mathrm{P}\right]$-ATP-labeled substrate. Protein concentration was determined according to the method of Bradford (1976). In the final assay $30 \mu \mathrm{g}$ of total protein in a volume of $20 \mu \mathrm{l}$ per sample was employed. mWBC extracts were added to $20 \mu$ of protein phosphatase assay buffer (consisting of $0.1 \mathrm{mM}$ EDTA, $20 \mathrm{mM}$ imidazole- $\mathrm{HCl}, \mathrm{pH} 7.63$, $1 \mathrm{mg} / \mathrm{ml} \mathrm{BSA}, 0.1 \%$ ( $\mathrm{v} / \mathrm{v})$ B-mercaptoethanol final concentration). The reaction was started by adding $20 \mu\left[{ }^{32} \mathrm{P}\right]$-phosphorylase a in solubilization buffer ( $50 \mathrm{mM}$ Tris- $\mathrm{HCl}, \mathrm{pH} 7.0,0.1 \mathrm{mM}$ EDTA, $15 \mathrm{mM}$ caffeine, $0.1 \%(\mathrm{v} / \mathrm{v})$ (3-mercaptoethanol). After incubation for $5 \mathrm{~min}$ at $30{ }^{\circ} \mathrm{C}$ the reaction was stopped by addition of $180 \mathrm{ml}$ ice-cold $20 \%$ (w/v) trichloroacetic acid and cooling on ice for at least $10 \mathrm{~min}$. Subsequently the samples were centrifuged for $5 \mathrm{~min}$ at $12,000 \times \mathrm{gg}$. In order to extract free $\left[{ }^{32} \mathrm{P}\right] 180 \mu \mathrm{l}$ of the resulting supernatants were mixed with $200 \mu \mathrm{J}$ of acid phosphate buffer $\left(1.25 \mathrm{mM} \mathrm{KH}_{2} \mathrm{PO}_{4}\right.$ in $\left.0.5 \mathrm{M} \mathrm{H}_{2} \mathrm{SO}_{4}\right), 500 \mu$ isobutanol/heptane (1:1) and $100 \mu$ ammoniumheptamolybdate $(5 \%(\mathrm{w} / \mathrm{v}))$ by vigorously vortexing. Radioactivity was counted in a liquid scintillation counter (LS 6500; Beckman Coulter, Krefeld, Germany) after mixing $300 \mu$ of the [ $\left.{ }^{32} \mathrm{P}\right]-$ containing solvent layer with $1 \mathrm{ml}$ of scintillation cocktail (Ready Safe: Beckman Coulter, Krefeld. Germany). Total ser/thr-specific protein phosphatase activity of MC- and OA- (positive control) exposed mWBC was calculated by determining the percentage loss of radioactivity from untreated cells (negative control $=100 \%$ activity). Each sample was analyzed three times in duplicate. The degree of protein phosphatase inhibition expressed as activity of the corresponding control was normalized to the corresponding number of viable cells. This was achieved via division of the mean protein phosphatase inhibition with the corresponding median of cytotoxicity (MTT assay) observed.

\section{Determination of mOatp transporters in $m W B C$}

RNA extraction. Total RNA was isolated from $\mathrm{mWBC}$ using the RNeasy Mini Kit (Qiagen, Hilden, Germany) according to the manufacturer's instructions. Column-bound total RNA was eluted with $60 \mu \mathrm{J}$ RNase-free water and purity was determined by the quotient $260 \mathrm{~nm} / 280 \mathrm{~nm}$ of optical density (OD). Stably transfected HEK293-
OATP1B3 (Komatsu et al., 2007) (cultured in MEM supplemented with $10 \% \mathrm{FBS}, 1 \%$ penicillin/streptomycin and $400 \mu \mathrm{g} / \mathrm{ml}$ G418-sulphate at $37^{\circ} \mathrm{C}$ and $5 \% \mathrm{CO}_{2}$ ) were employed as an internal OATP positive control. Culture medium was removed every $72 \mathrm{~h}$ until cells were used for the experiment ( $80-90 \%$ confluence).

Reverse transcription-polymerase chain reaction (RT-PCR). Each reaction was carried out in a final volume of $21 \mu \mathrm{l}$. Therefore $6.8 \mu \mathrm{l}$ of total RNA (1.3 $\mu \mathrm{g}), 3.2 \mu \mathrm{l}$ RNase-free water, $0.5 \mu \mathrm{l}$ random hexamer primer and $0.5 \mu$ oligo(dT) were incubated for $5 \mathrm{~min}$ at $70^{\circ} \mathrm{C}$ following $5 \mathrm{~s}$ at $25^{\circ} \mathrm{C}$ and chilled for at least $1 \mathrm{~min}$ on ice. Reaction buffer $(4 \mu \mathrm{L})$, $2 \mu \mathrm{l}$ dNTP mix, $0.5 \mu \mathrm{l}$ ribonuclease inhibitor and $1.5 \mu \mathrm{l}$ RNase-free water were added $\left(5 \mathrm{~min}, 25^{\circ} \mathrm{C}\right.$ ). Finally, $2 \mu$ of Reverse Transcriptase (RT) or RNase-free water (for RT negative controls) was incubated for $10 \mathrm{~min}$ at $25^{\circ} \mathrm{C}, 60 \mathrm{~min}$ at $37^{\circ} \mathrm{C}$ following $10 \mathrm{~min}$ at $70^{\circ} \mathrm{C}$.

PCR for mOatp/OATP was performed in $25 \mu \mathrm{l}$ reaction mixtures according to Mülhardt (2002) with minor modifications. Primers were designed (Primer3 software; Rozen and Skaletzky, 2000) re-hydrated with RNase-free water to the appropriate volumes according to MWBBiotech data sheets $\left(100 \mathrm{pmol} / \mathrm{L}^{\circ}\right)$, gently mixed and shaken over night at $4{ }^{\circ} \mathrm{C}$. The sequences of primer pairs used in this assay are shown in Table 1 . Briefly, amplification was subsequently carried out by mixing $2 \mu$ of cDNA product with $12.5 \mu$ of $2 \times$ PCR Master Mix solution, $4 \mu$ of the primer pair mix ( $0.5 \mu \mathrm{M}$ forward-and $0.5 \mu \mathrm{M}$ reverse primer) and $6.5 \mu$ of RNase-free water. Human OATP1B3 was used as a positive control. PCR reaction was performed in a thermocycler (Primus 96 Plus; MWG-Biotech, Martinsried, Germany) under the following conditions: initial denaturing for $3 \mathrm{~min}$ at $94{ }^{\circ} \mathrm{C}, 30$ cycles of denaturing for $1 \mathrm{~min}$ at $94{ }^{\circ} \mathrm{C}$, annealing for $1 \mathrm{~min}$ at $58{ }^{\circ} \mathrm{C}$ and elongation for $1 \mathrm{~min}$ at $72^{\circ} \mathrm{C}$ foliowed by an additional extension for 7 min at $72{ }^{\circ} \mathrm{C}$.

Agarose gel electrophoresis of PCR products. Each PCR product $(20 \mu \mathrm{l})$ was separated by gel electrophoresis on a $3 \%$ agarose gel buffered in TBE (10.8 g/l Tris-base, $5.5 \mathrm{~g} / \mathrm{l}$ boric acid, $4 \mathrm{ml}$ (v/v) $0.5 \mathrm{M}$ EDTA ph 8.0). DNA ladder (GeneRuler 100 bp; Fermentas, St. Leon-Rot, Germany) was employed to determine the PCR product size. Gels were stained by ethidium bromide, visualized under UV light $(302 \mathrm{~nm}$ ), photographed (Polaroid camera and Polaroid 667 films) and then scanned for documentation.

Purification and sequence confirmation of PCR products. Following $3 \%$ agarose gel separation of PCR products, bands were excised and the PCR products purified via microcolumn elution (QIAquick gel extraction kit; Qiagen, Hilden, Germany). Purified PCR products were sent to GATC (Konstanz, Germany) for DNA sequencing.

Table 1

Primer sequences used for PCR

\begin{tabular}{|c|c|c|c|c|}
\hline $\begin{array}{l}\text { Gene } \\
\text { (protein) }\end{array}$ & Primer & Sequence $5^{\prime} \rightarrow 3^{\prime}$ & $\begin{array}{l}\text { Product size } \\
\text { (base pairs) }\end{array}$ & $\begin{array}{l}\text { Degree of } \\
\text { alignment } \\
\text { (BLAST) (\%) }\end{array}$ \\
\hline Slcole1 (Oatp1c1) & $\begin{array}{l}\text { Sense } \\
\text { Antisense }\end{array}$ & $\begin{array}{l}\text { gtaggggattccagctcctc } \\
\text { gcataatgagcccaaaagga }\end{array}$ & 204 & 100 \\
\hline Slcolal (Oatpla1) & $\begin{array}{l}\text { Sense } \\
\text { Antisense }\end{array}$ & $\begin{array}{l}\text { atccagtgtgtggggacaat } \\
\text { atggctgcgagtgagaagat }\end{array}$ & 235 & 100 \\
\hline Slcola5 (Oatp1a5) & $\begin{array}{l}\text { Sense } \\
\text { Antisense }\end{array}$ & $\begin{array}{l}\text { gcacagagaaaaagccaagg } \\
\text { ctccaggtatttgggcaaga }\end{array}$ & 166 & 100 \\
\hline Slco3a1 (Oatp3a1) & $\begin{array}{l}\text { Sense } \\
\text { Antisense }\end{array}$ & $\begin{array}{l}\text { gccttttggtgaagaagctg } \\
\text { gaagcaggctgacaggtagg }\end{array}$ & 275 & 100 \\
\hline Slco 1 b2 (Oatp1b2) & $\begin{array}{l}\text { Sense } \\
\text { Antisense }\end{array}$ & $\begin{array}{l}\text { ttcaccacaacaatggccta } \\
\text { ttttccccacagacaggttc }\end{array}$ & 194 & 100 \\
\hline Slco6d1 (Oatp6d1) & $\begin{array}{l}\text { Sense } \\
\text { Antisense }\end{array}$ & $\begin{array}{l}\text { gaagcaggctcaggtggtag } \\
\text { acgaccgctaaaaacgacag }\end{array}$ & 249 & n.d. \\
\hline SLCO1B3 (OATP1B3) & $\begin{array}{l}\text { Sense } \\
\text { Antisense }\end{array}$ & $\begin{array}{l}\text { gggtgaatgcccaagagata } \\
\text { attgactggaaacccattgc }\end{array}$ & 168 & 100 \\
\hline
\end{tabular}

n.d.: not detectable due to limited band visibility and thus PCR product extraction. 
A

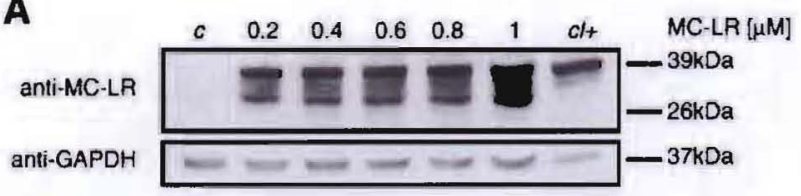

B

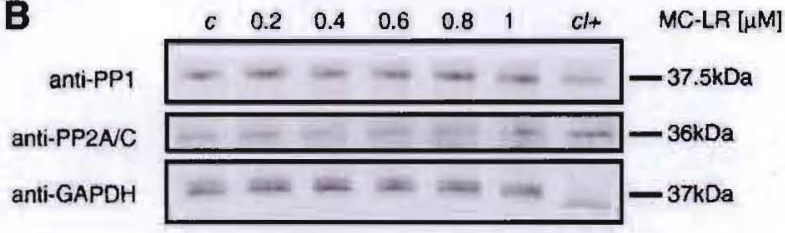

C

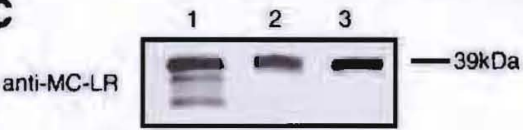

Fig. 2. (A) Determination of intracellular MC- $L R$ after 48 h exposure of mWBC to a rang of MC-LR concentrations. Western blots using MC-antibody MCLR\#2 (Mikhailov et al., 2001). c: control mWBC, cl+: $1 \mu \mathrm{M}$ MC-LR added to mWBC cell lysate: (B) Determination of intracellular PP1 $\alpha$ and PP2A/C expression in mWBC exposed to MC-LR. Western blots using PP1a and PP2A/C antibodies. (C) Determination of PP-associated MC-LR after $48 \mathrm{~h}$ exposure of mWBC. Lane 1: mWBC following exposure to 1 MM MC-LR, lane 2: purified rabbit muscle PPI (New England Biolabs, Germany) incubated with $1 \mu \mathrm{M}$ MC-LR in vitro, lane 3: purified human erythrocyte PP2A (Promega, Germany) incubated with 1 IMM MC-LR.

Sequence results received were aligned (http://blast.ncbi.nim.nih.gov/ bl2seq/wblast2.cgi) with the corresponding known mOATP/OATP1B3 sequences.

Investigation of mOatp $1 b 2$ protein expression in $m W B C$ via Western blot analysis

For analysis of mOatp1b2 via WB, mWBC were cultured and homogenized as described above. Briefly, the $\mathrm{MWBC}$ homogenate was centrifuged for $40 \mathrm{~min}$ at $16.000 \mathrm{xg}$ and $4^{\circ} \mathrm{C}$ in order to obtain the crude membrane fraction. The pellet was resuspended and protein concentration was determined by the method of Bradford (1976) (BioRad Protein Assay: Bio-Rad, Munich, Germany). Proteins were separated by SDS-PAGE, blotted on a nitrocellulose membrane and incubated with an antibody against mOatp1b2 (Lu et al., 2008), kindly provided by Prof. Klaassen (Department of Pharmacology, Toxicology and Therapeutics, University of Kansas Medical Center, Kansas, USA).

\section{Statistics}

Statistical analysis was performed by one-way analysis of variance (ANOVA) with Dunnett's post test, Bonferroni or Newman-Keuls

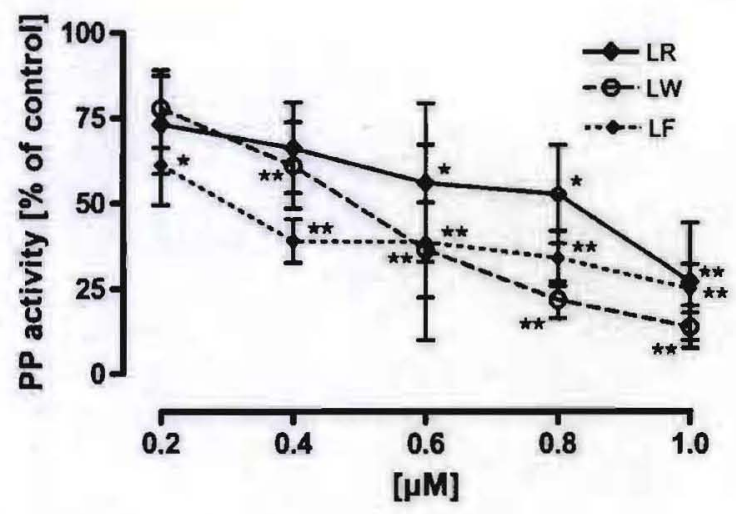

Fig. 4. Total protein phosphatase activity in mWBC after treatment with MC-congeners $\mathrm{LR},-\mathrm{LW}$, or $-\mathrm{LF}$ normalized to median of cytotoxicity. Values represent mean $\pm \mathrm{SD}$ of three independent experiments and are expressed as percentage of control. Statistics: one-way ANOVA with Dunnett's post-test $\left(P<0.05^{\text {"**; } ;} P<0.01^{\cdots * * *)}\right.$ ).

multiple comparison test, where appropriate, using GraphPad Prism 4.03, $P<0.05\left(^{*}\right), P<0.01\left(^{* *}\right)$ and $P<0.001\left(^{* * *}\right)$.

\section{Results}

Uptake of MC-LR into $M W B C$

A concentration-dependent uptake of MC-LR was observed in mWBC exposed to MC-LR for $48 \mathrm{~h}$ (Fig. 2A). MC-LR-positive bands ranged between $\sim 39$ and $\sim 28 \mathrm{kDa}$. The $\sim 39 \mathrm{kDa}$ band corresponded to the catalytic subunits of PP1 ( $37.5 \mathrm{kDa})$ and PP2A ( $36 \mathrm{kDa})$, as confirmed via immunoblotting using antibodies against $P P 1 \alpha$ and PP2A/C (Fig. 2B), yet in addition containing a covalently bound $1 \mathrm{kDa}$ MC. The latter was also confirmed by MC-incubation studies using purified PP1 and PP2A, which provided a comparable $\sim 39 \mathrm{kDa}$ band (Fig. 2C).

\section{Intracellular localization and cytotoxic effects in mWBC}

Incubation ( $48 \mathrm{~h}$ ) of $\mathrm{mWBC}$ with $0,0.6 \mathrm{\mu M}$ and $5.0 \mu \mathrm{M} \mathrm{MC}$-LR and subsequent immunofluorescent analyses using con-focal microscopy demonstrated the presence of MC-LR in the cytosol and the nuclei of $\mathrm{mWBC}$ (Figs. 3B and C). Loss of structural integrity of the cytoskeleton was MC-LR concentration-dependent, as shown by the congregation of actin filaments around the nuclei (Figs. 3B and C). Loss of cytoskeleton integrity also coincided with protein phosphatase inhibition (Fig. 4) but not directly to cytotoxicity as determined via MTT assay (Fig. 4). However, complete congregation of actin filaments around the nuclei (Fig. 3C) as observed following incubation with $5 \mu \mathrm{M}$
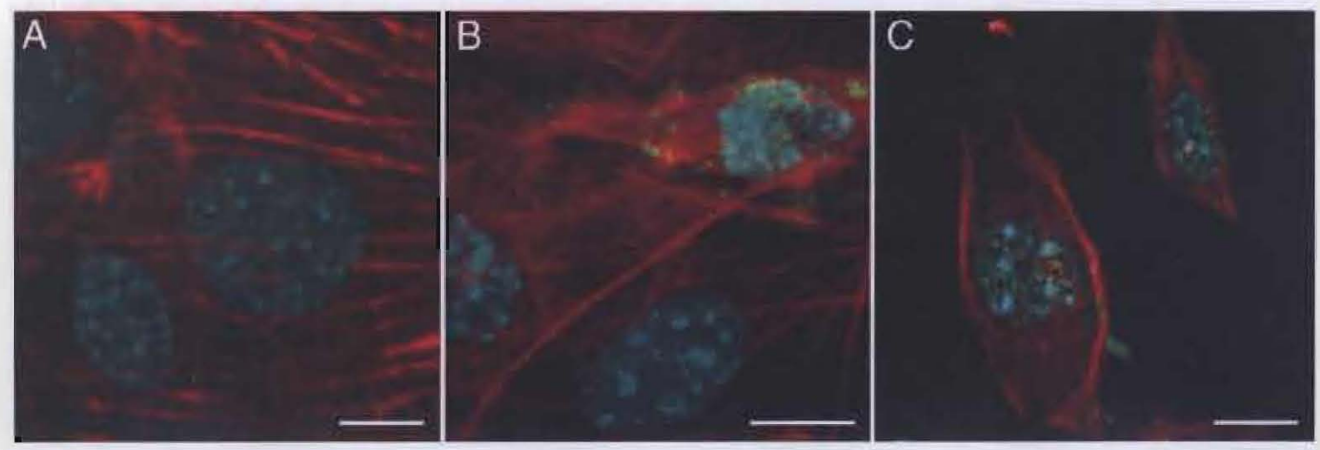

Fig. 3. Intracellular MC-LR localization and associated cytoskeleton abnormalities in mWBC exposed to MC-LR for $48 \mathrm{~h}$. Immunolabeling of MC-LR (green: MCLR\#2-Alexa488), actin filaments (red: TRITC-Phalloidin) and nucleus (blue: Hoechst 33342); (A) control mWBC; (B) mWBC exposed to $0.6 \mu \mathrm{M}$ MC-LR; (C) mWBC exposed to $5 \mu \mathrm{M}$ MC-LR. Scale bar 10 um. 


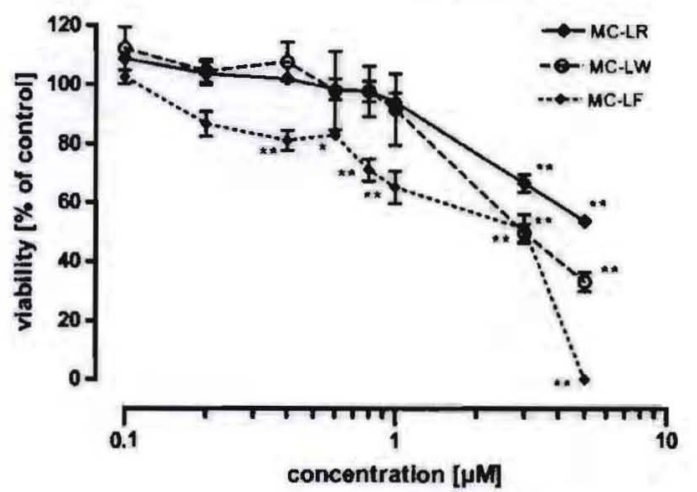

Fig. 5. Cytotoxicity in mWBC following $48 \mathrm{~h}$ exposure to MC-LR, -LW, and -LF (conc. range $0.1-5 \mu M$ ), determined via MTr. Viability values represent mean \pm SEM of three independent experiments and are expressed as percentage of control. Statistics: one-way ANOVA with Dunnett's post-test $\left(P<0.05^{n * n ;} P<0.01\right.$ "**").

MC-LR corresponded to approximately $40 \%$ reduction in cell viability, as determined via MTT.

\section{MC-congener specific cytotoxic effect}

Exposure of $m W B C$ for $48 \mathrm{~h}$ to MC-LF, - LW and -LR resulted in significant inhibition of protein-phosphatase in mWBC (Fig. 4) at $\geq 200 \mathrm{nM}, \geq 400 \mathrm{nM}$ and $\geq 600 \mathrm{nM}$, respectively. Protein-phosphatase inhibition corresponded with the observed cytotoxicity at the highest concentrations (Fig. 5). Indeed, while exposure of $\mathrm{mWBC}$ to $5 \mu \mathrm{M} \mathrm{MC}$ LF resulted in a complete loss of viable cells, the same concentrations of MC-LW and -LR resulted only in a $33 \%$ and $54 \%$ reduction of cell viability, respectively.

\section{Determination of mOatp-associated transport of MC}

To further evaluate the role of bile acid transporters in the active uptake of different MC congeners into $\mathrm{MWBC}$, the presence of various mOatps was examined at the mRNA level. $\mathrm{MWBC}$ were screened for six mOatps (Oatp1c1, 1a5, 3a1, 1a1, 1b2 and 6d1) and resulted in single positive bands for five tested mOatps (Oatp1c1, 1a5, 3a1, 1a1 and 1b2) with 166-275 bp corresponding to the expected size of amplified products with the primers employed (Fig. 6 ). Water and RT negative controls did not show any contamination/bands (data not shown). The amplified products were sequenced to confirm the detection of the visualized mOatp fragments. While five of the six mOatp RT-PCR products could be confirmed via sequencing and alignment analysis (Table 1), there was insufficient DNA extractable for mOatp6d1 (Slco6d1) to allow sequence confirmation. In addition, mOatp1b2 was detectable in $\mathrm{mWBC}$, whole brain and liver homogenates (positive control, (Lu et al., 2008)) at the protein level (Fig. 7) with a molecular weight of 70-80 kDa (www.uniprot.org: UniProtKB/Swiss-ProtQ9JJL31(SO1B2_Mouse), mOatp1b2 known molecular weight $76.729 \mathrm{kDa}$ ).

In order to corroborate the association of mOatp with the active uptake of MC congeners in $\mathrm{MWBC}$, co-incubation studies were carried out employing excess concentrations of the OATP/Oatp substrates TC

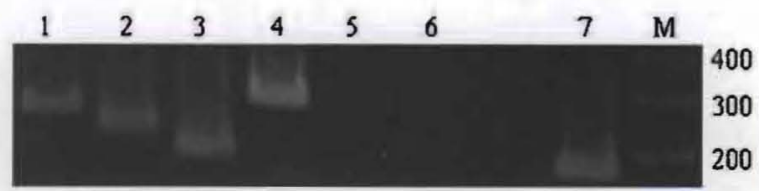

Fig. 6. RT-PCR of Oatp-mRNA expression in $\mathrm{mWBC}$. Lane 1: Oatp1a1; lane 2: Oatp1c1; lane 3: Oatp1a5; lane 4: Oatp3a1; lane 5: Oatp6d1; lane 6: Oatp1b2; lane 7: OATP1B3 (positive control: stably transfected HEK293-OATP1B3). M: Gene ruler (bp).

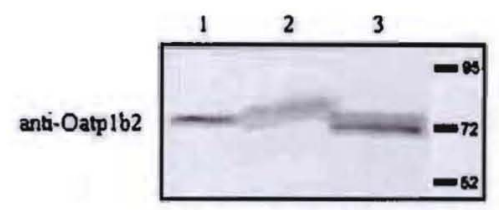

Fig. 7. Western blot of mOatp1b2 in mWBC crude membrane fractions using an antiOatp 1b2 polyclonal antibody (Lu et al., 2008). Lane 1: mWBC ( $40 \mu \mathrm{g})$; lane 2 : murine brain homogenate ( $40 \mu \mathrm{g}$ ); lane 3: murine liver homogenate (positive control, $40 \mu \mathrm{g}$ ).

and BSP (Jacquemin et al., 1994; Runnegar et al., 1995; Kanai et al., 1996; Fischer et al., 2005; Monks et al., 2007). The viability of mWBC exposed to MCs was compared to $\mathrm{MWBC}$ exposed to the combination of 50 and $500 \mu \mathrm{M} \mathrm{TC}$ (Figs. 8B, C, E, F, H, I) or $50 \mu \mathrm{M}$ BSP (Figs. 8A, D, G) and the corresponding MCs. Co-incubation of TC and BSP with MCs generally resulted in a reduction of observed cytotoxicity. For MC-LR this reduced cytotoxicity was observed at $\geq 5 \mu \mathrm{M} M C$-LR only, whereas reduced cytotoxicity was already observed at 1 and $3 \mu \mathrm{M}$ for MC-LW and -LF, respectively. Moreover, while the reduction of cytotoxicity in MC-LW and -LF exposed mWBC co-incubated with 50 um BSP was limited, the corresponding experiments with 50 and $500 \mu \mathrm{M}$ TC demonstrated a much greater reduction in MC-mediated cytotoxicity. Provided that MC is primarily transported via mOatps, the data as presented here suggest better MC transport-inhibition by TC than by BSP, despite that the degree of reduction in MC-mediated cytotoxicity was comparable in the 50 and $500 \mu \mathrm{M} \mathrm{TC}$ co-incubation experiments.

TC-induced reduction of MC transport was also corroborated by Western blots demonstrating smaller protein bands positive for MCLW in cells co-incubated with TC than in cells exposed to MC-LW only (Fig. 9). Moreover, the width of the MC-LW positive protein bands decreased in a MC-LW concentration (1.0-0.05 $\mu \mathrm{M}$ MC-LW) dependent manner, being smallest in cells exposed to $50 \mathrm{nM} \mathrm{MC}-\mathrm{LW}$ and $500 \mu \mathrm{M} \mathrm{TC}$.

\section{Discussion}

Contamination of human water sources with the cyanobacterial toxin MC has been shown to induce hepato- and neurotoxic effects in patients of a dialysis clinic in Caruaru, Brazil (Pouria et al., 1998). The early onset of neurotoxicity observed could be explained by the uptake of MCs via OATPS e.g. OATP1A2 which is highly expressed in endothelial cells of the BBB, epithelial cells of the BCFB and in the membrane of human neurons (Kullak-Ublick et al., 1995; Gao et al., 2000; Fischer et al., 2005; Gao et al., 2005; Lee et al., 2005; Nies, 2007). However, neurotoxicity can only evolve if MCs are actively and effectively transported, e.g. via MC-transport competent Oatp/OATP, or possibly other yet unknown transporters, expressed in brain cells. Transport of MC-LR has been demonstrated for human OATP1A2, 1B1, 1B3, rat/mouseOatp1b2 and scateOatp1d1 (Fischer et al., 2005; Komatsu et al., 2007; Meier-Abt et al., 2007; Monks et al., 2007; Lu et al., 2008) but not for the human OATP2B1 and rat Oatp 1a1 and $1 \mathrm{a} 4$ (Fischer et al., 2005), thus demonstrating that not all Oatp/OATP are capable of transporting MC-LR. The latter however also raised the question whether different MC congeners are transported by different Oatp/OATP albeit with varying efficiency, thereby suggesting that an Oatp/OATP not transporting MC-LR does not exclude its capability of transporting other $\mathrm{MC}$ congeners.

The results presented in this study, clearly demonstrate the expression of at least five mOatps in primary murine whole brain cells (Fig. 6) at the mRNA level. The different band intensities as observed in Fig. 6 most likely result from varying binding efficiencies of the respective primers generated to the respective mWBC mOatp mRNAs.

The detection of the liver specific MC-LR transporter Oatp1b2 (mouse, rat) (Fischer et al., 2005; Lu et al., 2008) in liver and brain homogenates as well as in mWBC at the protein level(Fig. 7), suggests 

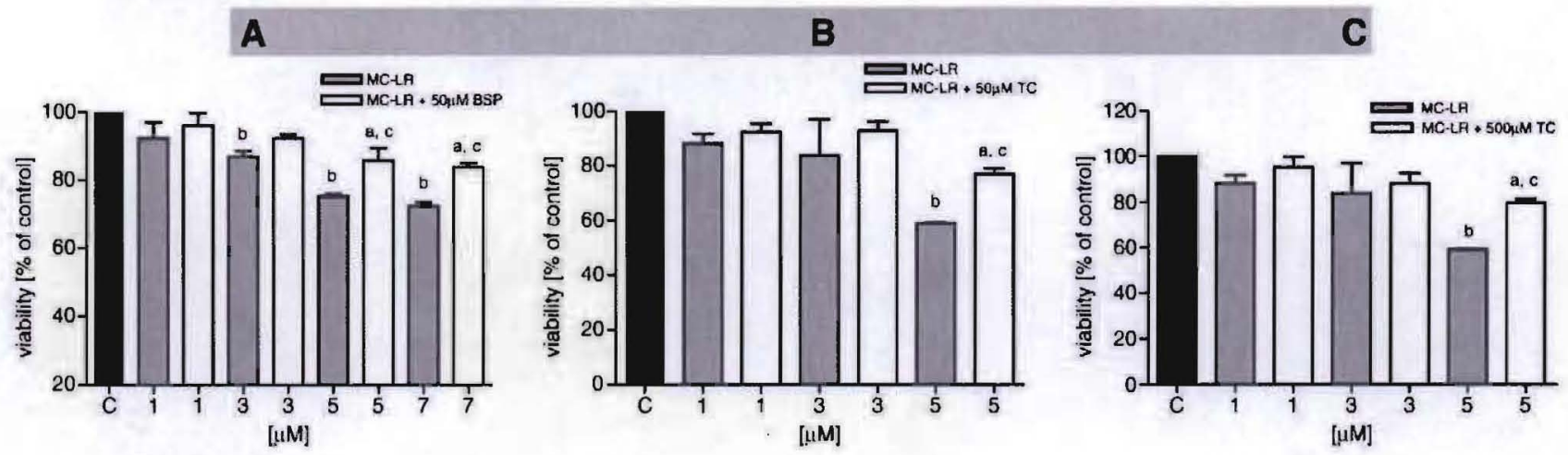

MC-LW

D E
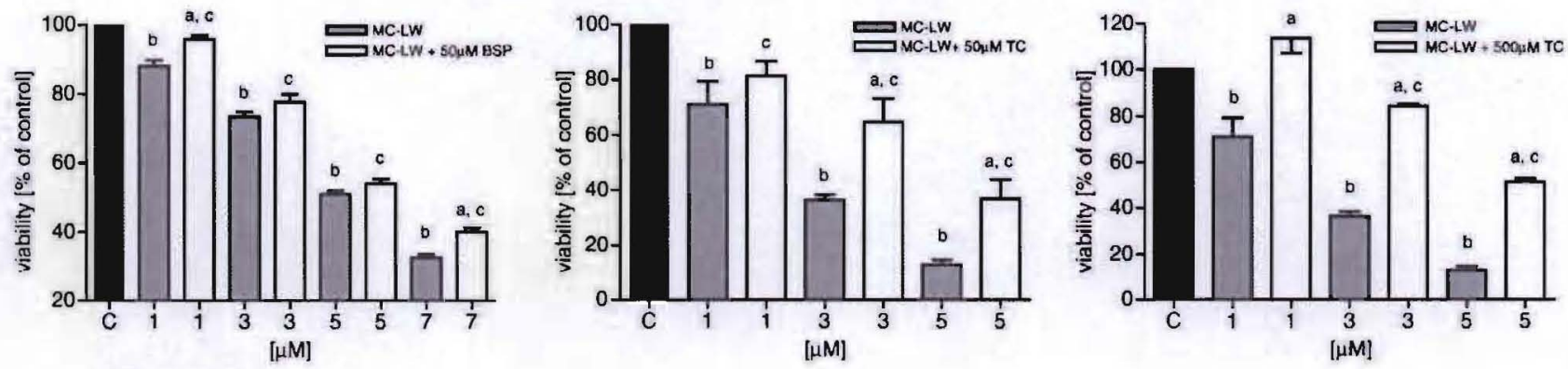

MC-LF
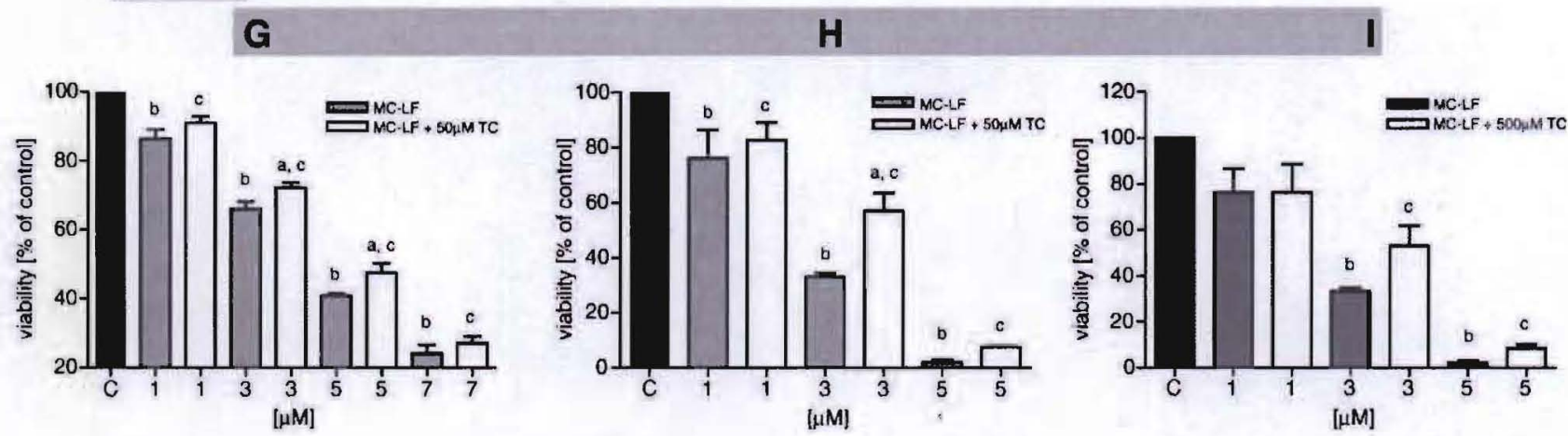

Fig. 8. Cytotoxic effects of MC-LR (A, B, C), -LW (D, E, F), -LF (G, H, I) in mWBC co-incubated with/without the Oatp substrates taurocholate (TC: 50 and $500 \mu \mathrm{M})$ and bromosulfophthalein (BSP: $50 \mu \mathrm{M}$ ). Control mWBC (C: black columns) represent $100 \%$ cell viability, MC-congener treated mWBC (grey columns) and MC-congener \pm TC/BSP coincubated mWBC (white columns) following 48 h exposure. Values represent mean \pm SEM of three independent experiments. Statistics: one-way ANOVA with Newman-Keuls multiple comparison test (comparison of $a$ : MC vs. MC+BSP/TC; $b$ : MC vs. control; c: MC+BSP/TC vs. control, all at $P<0.05$ ).

the functional expression of mOatp1b2 in mouse brains and $\mathrm{mWBC}$. As Oatp1b2 (mouse, rat) was demonstrated to actively transport MCLR the observed MC-mediated cytotoxicity and PP inhibition in $\mathrm{mWBC}$ may be at least partially due to mOatp $1 \mathrm{~b} 2$ mediated MC transport into $\mathrm{mWBC}$. However, other mOatps may also be involved in the transport of MCs, since Oatp1b2 knock-out mice have shown to develop no overt hepatotoxicity, albeit detectable MC-LR was observed in liver homogenates (Lu et al., 2008). Incubation of $\mathrm{mWBC}$ with the three different $M C$ congeners MC-LR, - LW and - LF resulted in congener-dependent toxicity as demonstrated by the observed concentration-dependent cytotoxicity (Fig. 5) and protein phosphatase inhibition (Fig. 4). Moreover, the observed variant cytotoxicity with the three different
MC congeners (Fig. 8) in conjunction with the findings by Lu et al. (2008) suggests that although mOatp1b2 efficiently transports MC-LR, mOatp1b2 mediated MC transport may not be as important in mouse brains and that other mOatp, expressed at higher levels than mOatp1b2, as well as MC congeners other than MC-LR may be more important for MC-mediated neurotoxicity. However, only specific expression of individual mOatp and MC-transport analyses, as discussed below, will allow determination of the contribution of each individual mOatp expressed in $\mathrm{MWBC}$ and mouse brains in the observed MC-congener specific transport.

Intracellular localization of MCs was proven via immunocytochemistry (Fig. 3) and Western blotting of mWBC cell homogenates 


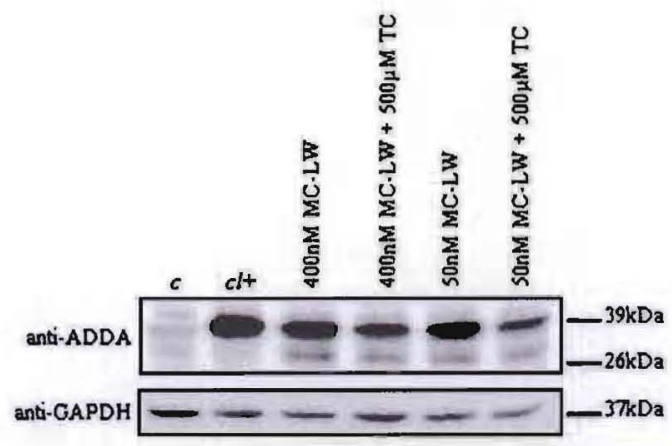

Fig. 9. Oatp-dependent uptake of $\mathrm{MC}-\mathrm{LW}$ in $\mathrm{mWBC}$ following $48 \mathrm{~h}$ co-incubation with/ without the Oatp substrate taurocholate (TC: $500 \mu \mathrm{M}$ ). Westem blot using anti-ADDA antibody (clone $\mathrm{AD} 4 \mathrm{G} 2$ ) for MC-LW adduct detection.

(Figs. 2 and 9), thus conclusively demonstrating transport of MCs into mWBC. mOatp-associated MC transport, is also supported by the fact that uptake of MCS into MWBC, as indicated by the observed cytotoxicity (Fig. 8) and MC-Western blotting of cell homogenates (Fig. 9), was reduced upon co-incubation of MWBC with the OATP/ Oatp substrates TC and BSP. Both $50 \mu \mathrm{M}$ BPS as well as 50 and $500 \mu \mathrm{M}$ TC reduced uptake of MC congeners, albeit TC with a much greater efficacy than BSP. Provided that the observed MC cytotoxicity is mediated via mOatp dependent transport, the observed differences in reduction of MC-congener dependent cytotoxicity by BSP and TC may stem from varying affinities of the three MC-congeners, TC and BSP for the mOatp detected in the mWBC employed. However, only specific expression of these mOatp, e.g. in Xenopus oocytes (Fischer et al., 2005), HeLa (Monks et al., 2007) or HEK293 celis (Komatsu et al., 2007) and subsequent kinetic analyses of MC-congener dependent transport would allow deduction whether the mOatps in mWBC are primarily responsible for $M C$ transport.

The data of this study thus suggest that MC-LF and MC-LW have a much higher potential for inducing neurotoxicity in mice than MC-LR. Consequently, based on the high similarities of mOatp with human OATP, a more thorough investigation of different MC congeners appears important for proper assessment of microcystin toxicity, including neurotoxicity, and cancer risk in humans, rather than relying on MC-LR risk assessment (WHO, 1998).

\section{Acknowledgments}

This study was supported by the International Research Training Group 1331 (IRTG 1331). We would like to thank, Dr. Elisa May (Bio Imaging Centre, University of Konstanz, Germany) for the introduction to con-focal microscopy, Prof. Dietrich Keppler (Division of Tumor Biochemistry, German Cancer Research Centre, Heidelberg, Germany) for providing stably transfected HEK293-OATP1B3 and Alexandra Heussner for the technical support. Special thanks are due to Dr. Bernhard Ernst for his great support with the rPPIA assay and for his contributions to this project. The editorial review of the manuscript by Dr. Evelyn O'Brien is gratefully acknowledged. Finally we would like to thank Oliver Okle for the technical assistance.

\section{References}

Abe, T., Kakyo, M., Tokui, T., Nakagomi, R., Nishio, T., Nakai, D., Nomura, H., Unno, M., Suzuki, M., Naitoh, T. Matsuno, S, Yawo, H., 1999. Identification of a novel gene family encoding human liver-specific organic anion transporter LSI-1. J. Biol. Chem. $274,17159-17163$.

Azevedo, S.M., Carmichael, W.W., Jochimsen, E.M., Rinehart, K.L., Lau, S., Shaw, G.R., and Eaglesham, G.K. (2002). Human intoxication by microcystins during renai dialysis treatment in Caruaru-Brazil. Toxicology 181-182, 441-446.

Batista, T., de Sousa, G., Suput, J.S., Rahmani, R., Suput, D., 2003. Microcystin-IR causes the collapse of actin filaments in primary human hepatocytes. Aquat. Toxicol. 65, $85-9$
Bergwerk, A.J., Shi, X., Ford, A.C., Kanai, N., Jacquemin, E., Burk, R.D., Bai, S., Novikoff, P.M., Stieger, B. Meier, P. Schuster, V.L. Wolkoff, A.W. 1996. Immunologic distribution of an organic anion transport protein in rat liver and kidney. Am. J. Physiol. 271. G231-G238.

Bologa, L., Joubert, R., Bisconte, J.C., Margules, S., Deugnier, M.A., Derbin, C. Herschkowitz, N.., 1983. Development of immunologically identified brain cells in culture: quantitative aspects. Exp. Brain Res. 53, 163-167.

Bradford, M.M., 1976. A rapid and sensitive method for the quantification of microgram quantities of protein utilizing the principle of protein-dye binding. Analytical Biochemistry 72, 248-254.

Carmichael, W.W. Azevedo, S.M. An, IS. Molica, R.J. Jochimsen, E.M., Lau, S., Rinehart, K.L., Shaw, G.R., Eaglesham, G.K., 2001. Human fatalities from cyanobacteria: chemical and biological evidence for cyanotoxins. Environ. Health Perspect. 109, 663-668.

Cheng, X., Maher, J., Chen, C., Klaassen. C.D., 2005. Tissue distribution and ontogeny of mouse organic anion transporting polypeptides (Oatps). Drug Metab. Dispos. 33. 1062-1073.

Eriksson, J.E., Paatero, G.I.L., Meriluoto, J.A.O., Codd, G.A., Kass, G.E.N., Nicotera, P, Orrenius, S., 1989. Rapid microfilament reorganization induced in isolated rat hepatocytes by microcystin-IR, a cyclic peptide toxin. Exp. Cell Res, 185, 86-100.

Eriksson. J.E., Toivola, D., Meriluoto, J.A., Karaki, H., Han, Y.G., Hartshorne, D., 1990. Hepatocyte deformation induced by cyanobacterial toxins reflects inhibition of protein phosphatases. Biochem. Biophys. Res. Commun. 173, 1347-1353.

Falconer, I.R. Smith, JV., Jackson, A.R., Jones, A., Runnegar, M.T., 1988. Oral toxicity of a bloom of the Cyanobacterium microcystis Aeruginosa administered to mice over periods up to 1 year. J. Toxicol. Environ. Health 24, 291-305.

Fischer, W.J., Altheimer, S., Cattori, V., Meier, P.J., Dietrich, D.R., Hagenbuch, B., 2005. Organic anion transporting polypeptides expressed in liver and brain mediate uptake of microcystin. Toxicol. Appl. Pharmacol, 203, 257-263.

Fischer, W.j.. Dietrich, D.R., 2000a. Pathological and biochemical characterization of microcystin-induced hepatopancreas and kidney damage in carp (Cyprinus carpio). Ioxicol. Appl. Pharmacol. 164, 73-81.

Fischer. W.J. Hitzfeld, B.C. Tencalla, F. Eriksson, J.E. Mikhailov, A. Dietrich, D.R. 2000b. Microcystin-LR toxicodynamics, induced pathology, and immunohistochemical localization in livers of blue-green algae exposed rainbow trout (Oncorhynchus mykiss). Toxicol. Science 54, 365-373.

Fischer, W.J., Dietrich, D.R., 2000c. Toxicity of the cyanobacterial cyclic heptapeptide toxins microcystin-LR and -RR in early life-stages of the African clawed frog (Xenopus laevis). Aquatic Toxicology 49, 189-198.

Fladmark, K.E.. Brustugun, O.T., Mellgren, G., Krakstad, C., Boe. R., Vintermyr, O.K., Schulman, H., Doskeland, S.O., 2002. Ca2+/calmodulin-dependent protein kinase II is required for microcystin-induced apoptosis. J. Biol. Chem. 277, 2804-2811.

Fu, W.Y., Chen, J.P., Wang. X.M. Xu, L.H., 2005. Altered expression of p53, Bcl-2 and Bax induced by microcystin-LR in vivo and in vitro. Toxicon, 46, 171-177.

Gao, B., Hagenbuch, B., Kullak-Ublick, G.A., Benke, D., Aguzzi, A., Meier, P.J., 2000. Organic anion-transporting polypeptides mediate transport of opioid peptides across blood-brain barrier. J. Pharmacol, Exp. Ther 294, 73-79.

Gao, B., Huber, R.D., Wenzel, A., Vavricka, S.R., Ismair, M.G., Reme, C., Meier, P.Jn 2005. Localization of organic anion transporting polypeptides in the rat and human ciliary body epithelium. Exp. Eye Res, 80, 61-72.

Gehringer, M.M. 2004. Microcystin-LR and okadaic acid-induced cellular effects: a dualistic response. FEBS Lett. 557, 1-8.

Gilroy, D.J., Kauffman, K.W. Hall, R.A., Huang, X., Chu, F.S., 2000. Assessing potential health risks from microcystin toxins in biue-green algae dietary supplements. Environmental Health Perspectives 108, 435-439.

Hagenbuch, B., Meier, P.J., 2003. The superfamily of organic anion transporting polypeptides. Biochim. Biophys. Acta. 1609, 1-18

Hagenbuch, B., Meier, P.J., 2004. Organic anion transporting polypeptides of the OATP/ SIC21 family: phylogenetic classification as OATP/SLCO superfamily, new nomenclature and molecular/functional properties. Pflugers. Arch. 447, 653-665.

Hastie, C.., Borthwick, E.B., Morrison, L.F, Codd, G.A., Cohen, P.T., 2005. Inhibition of several protein phosphatases by a non-covalently interacting microcystin and a novel cyanobacterial peptide, nostocyclin. Biochim. Biophys. Acta. 1726, 187-193.

Ito, E., Kondo, F., Harada, K.. 2000. First report on the distribution of orally administered microcystin-IR in mouse tissue using an immunostaining method. Toxicon. 38, $37-48$.

Jacquemin. E., Hagenbuch, B., Stieger, B., Wolkoff, A.W., Meier, P.j.. 1994. Expression cloning of a rat liver $\mathrm{Na}(+)$-independent organic anion transporter. Proc. Natl. Acad. Sci, U S A 91, 133-137.

Jochimsen, E.M., Carmichael, W.W., An, J.S., Cardo, D.M., Cookson, S.T., Holmes, C.E., Antunes, M.B., de Melo Filho, D.A., Lyra, T.M., Barreto, V.S., Azevedo. S.M.. Jarvis, W.R., 1998. Liver failure and death after exposure to microcystins at a hemodialysis center in Brazil. N. Engl. J. Med. 338, 873-878.

Kanai, N., Lu, R., Bao, Y., Wolkoff, A.W., Schuster, V.L., 1996. Transient expression of oatp organic anion transporter in mammalian cells: identification of candidate substrates. Am. J. Physiol. 270, F319-F325.

Komatsu, M., Furukawa, T. Ikeda, R., Takumi, S., Nong, Q., Aoyama, K., Akiyama, S. Keppler, D. Takeuchi, T. 2007. Involvement of mitogen-activated protein kinase signaling pathways in microcystin-LR-induced apoptosis after its selective uptake mediated by OATP1B1 and OATPIB3. Toxicol. Sci. 97, 407-416.

König. J., Cui, Y., Nies, A.T., Keppler, D., 2000a. A novel human organic anion transporting polypeptide localized to the basolateral hepatocyte membrane. Am. J. Physiol. Gastrointest. Liver Physiol. 278, G156-G164.

König. J., Cui, Y., Nies, A.T., Keppler, D., 2000b. Localization and genomic organization of a new hepatocellular organic anion transporting polypeptide. J. Biol. Chem. 275, 23161-23168. 
Kullak-Ublick, G.-A., Hagenbuch, B., Stieger, B., Wolkoff, A.W., Meier, P.., 1994 Functional characterization of the basolateral rat liver organic anion transporting polypeptide. Hepatology 20, 411-416,

Kullak-Ublick, G.A., Hagenbuch, B., Stieger, B., Schteingart, C.D., Hofmann, A.F., Wolkoff, A.W. Meier, P. .., 1995. Molecular and functional characterization of an organic anion transporting polypeptide cloned from human liver Gastroenterology 109, 1274-128

Kullak-Ublick, G.A., Stieger, B., Meier, P.J., 2004. Enterohepatic bile salt transporters in normal physiology and liver disease. Gastroenterology 126, 322-342.

Lawrence, J.F., Niedzwiadek, B., Menard, C., Lau, B.P., Lewis, D., Kuiper-Goodman, T. Carbone, S., Holmes, C., 2001. Comparison of liquid chromatography/mas spectrometry, ELISA, and phosphatase assay for the determination of microcystins in blue-green algae products. Journal of the AOAC intemational 84, 1035-1044

Laemmli, U.K., 1970. Cleavage of structural proteins during the assembly of the head of bacteriophage T4, Nature 227, 680-685.

Lee, W., Glaeser, H., Smith, L.H., Roberts, R.L., Moeckel, G.W., Gervasini, G., Leake, B.F. Kim, R.B., 2005. Polymorphisms in human organic anion-transporting polypeptide IA2 (OATP1A2): implications for altered drug disposition and central nervous system drug entry. J. Biol. Chem. 280, 9610-9617.

Lu, H., Choudhuri, S., Ogura, K., Csanaky, I.L., Lei, X., Cheng, X., Song, P.Z., Klaassen, C.D. 2008. Characterization of organic anion transporting polypeptide 1b2-null mice: essential role in hepatic uptake/toxicity of phalloidin and microcystin-LR. Toxicol. Sci. 103, 35-45.

MacKintosh, C., Beattie, K.A., Klumpp, S., Cohen, P.. Codd, C.A., 1990. Cyanobacterial microcystin-LR is a potent and specific inhibitor of protein phosphatases 1 and $2 A$ from both mammals and higher plants. FEBS Lett. 264, 187-192.

Mackintosh, C., MacKintosh, R.W.. 1994. Inhibitors of protein kinases and phosphatases. Trends in Biochemical Science 19, 444-448.

Mankiewicz, J. Tarczynska, M., Fladmark, K.E., Doskeland, S.O., Walter, Z., Zalewski, M. 2001. Apoptotic effect of cyanobacterial extract on rat hepatocytes and human lymphocytes. Environ. Toxicol. [print] 16, 225-233.

Meier-Abt, F, Hammann-Hanni, A., Stieger, B., Ballatori, N., Boyer, J.L., 2007. The organic anion transport polypeptide 1d1 (Oatp1d1) mediates hepatocellular uptake of phalloidin and microcystin into skate liver. Toxicol. Appl. Pharmacol. 218, 274-279.

Meriluoto, J.A., Nygard, S.E., Dahlem, A.M., Eriksson, J.E., 1990. Synthesis, organotropism and hepatocellular uptake of two tritium-labeled epimers of dihydromicrocystin $L R$, a cyanobacterial peptide toxin analog. Toxicon. 28, 1439-1446.

Meriluoto, J.A., Spoof, LE., 2008. Cyanotoxins: sampling, sample processing and toxin uptake. Adv. Exp. Med. Biol. 619, 483-499.

Mikhailov, A., Harmala-Brasken, A.-S., Polosukhina, E., Hanski, A., Wahlsten, M. Sivonen, K.. Eriksson. J.E., 2001. Production and specificity of monoclonal antibodies against nodularin conjugated through $\mathrm{N}$-methyldehydrobutyrine. Toxicon. 39 , 1453-1459.

Mikkaichi, T., Suzuki, T., Tanemoto, M., Ito, S., Abe, T., 2004. The organic anion transporter (OATP) family, Drug Metab. Pharmacokinet. 19, 171-179.

Monks, N.R., Liu, S., Xu, Y., Yu, H., Bendelow, A.S., Moscow. J.A., 2007. Potent cytotoxicity of the phosphatase inhibitor microcystin IR and microcystin analogues in OATP1B1-and OATP1B3-expressing HeLa cells. Mol. Cancer Ther, 6, 587-598.
Mosmann, T., 1983. Rapid colorimetric assay for cellular growth and survival: application to proliferation and cytotoxicity assays. J. Immunol. Methods 65, 55-63.

Mülhardt, C., 2002. Der Experimentator: Molekularbiologie, 3. Aufl., Spektrum, Heidelberg, Germany.

Naud, J., Michaud, J., Boisvert, C., Desbiens, K., Leblond, F.A., Mitchell, A., Jones, C, Bonnardeaux, A., Pichette, V., 2007. Down-regulation of intestinal drug transporters in chronic renal failure in rats. J. Pharmacol. Exp. Ther. 320, 978-985.

Nies, A.T. 2007. The role of membrane transporters in drug delivery to brain tumors. Cancer lett. 254, 11-29.

Nishiwaki, R., Ohra, T., Eisaburo, S., Suganuma, M., Harada, K.-l., Watanabe, M.F., Fujiki, H., 1994. Two significant aspects of microcystin-LR: specific binding and liver specificity. Cancer Lett. 83, 283-289.

Pouria, S., de Andrade, A., Barbosa, J., Cavalcanti, R. L., Barreto, V.T., Ward, C..., Preiser, W. Poon, G.K., Neild, G.H., Codd, G.A., 1998. Fatal microcystin intoxication in haemodialysis unit in Caruaru, Brazil. Lancet 352, 21-26.

Rozen, S., Skaletzky, H.J., 2000. Primer3 on the WWW for general users and biologist programmers. In: Krawetz, S., Misener, S. (Eds.), Bioinformatic Methods and Protocols: Methods in Molecular Biology. Human Press, Totowa, NJ. pp. 365-386.

Runnegar, M., Berndt, N., Kaplowitz, N., 1995. Microcystin uptake and inhibition of protein phosphatases: effects of chemoprotectants and self-inhibition in relation to known hepatic transporters. Toxicol. Appl. Pharmacol. 134, 264-272.

Runnegar, M.T., Gerdes, R.G., Falconer, I.R., 1991. The uptake of the cyanobacterial hepatotoxin microcystin by isolated rat hepatocytes. Toxicon. 29, 43-51.

Sai, Y., Kaneko, Y., Ito, S., Mitsuoka, K., Kato, Y., Tamai, I., Artursson, P., Tsuji, A., 2006 Predominant contribution of organic anion transporting polypeptide OATP-B (OATP2BI) to apical uptake of estrone-3-sulfate by human intestinal Caco-2 cells. Drug Metab. Dispos. 34, 1423-1431.

Schaeffer, D. Malpas, P., Barton, L. 1999. Risk assessment of microcystin in dietary Aphanizomenon flos-aquae. Ecotoxicology and Environmental Safety 44, 73-80.

Soares, R.M.. Yuan, M., Servaites, J.C., Delgado, A., Magalhaes, V.F., Hilborn, E.D., Carmichael, W.W. Azevedo, S.M., 2006. Sublethal exposure from microcystins to renal insufficiency patients in Rio de janeiro, Brazil. Environ. Toxicol. 21, 95-103.

Tani, T., Gram, L.K. Arakawa, H., Kikuchi, A., Chiba, M. Ishii, Y., Steffansen, B., Tamai, I., 2008 Involvement of organic anion transporting polypeptide 1 a5 (Oatp1 125 ) in the intestinal absorption of endothelin receptor antagonist in rats. Pharm. Res. 25, 1085-1091.

Tobwin, H., Staehelin, T., Gordon, J., 1979. Electrophoretic transfer of proteins from polyacrylamide gels to their nitrocellulose sheet. Procedure and some applications. Proc. Natl. Acad. Sci. U.S.A. 76, 4350-4354.

Toivola, D.M., Eriksson, J.E., Brautigan, D.L., 1994. Identification of protein phosphatase $2 \mathrm{~A}$ as the primary target for microcystin-LR in rat liver homogenates. FEBS Lett. 344 $175-180$.

Weng, D., Lu, Y., Wei, Y., Liu, Y., Shen, P., 2007. The role of ROS in microcystin-LR-induced hepatocyte apoptosis and liver injury in mice. Toxicology 232, 15-23.

WHO, 1998. Cyanobacterial toxins: microcystin-LR. Guidelines for Drinking-Water Quality. World Health Organization, Geneva, pp. 95-110.

Wickstrom, M.L., Khan, S.A., Haschek, W.M. Wyman, J.F. Eriksson, J.E., Schaeffer, D.J. Beasley, V.R. 1995. Alterations in microtubules, intermediate filaments, and microfilaments induced by microcystin-LR in cultured cells. Toxicol. Pathol. 23, 326-337. 